\title{
Effects of continuous Hormone Replacement Therapy (HRT) on FSH, lipid profiles, blood chemistry, and skin thickness in menopausal women
}

\author{
A. Baziad
}

\begin{abstract}
Abstrak
Penelitian ini bertujuan untuk melihat efek pemberian TSH estradiol $2 \mathrm{mg}+1 \mathrm{mg}$ noretisteron asetat secara kontinyu terhadap hormon FSH, profil lipid, kimia darah, serta ketebalan kulit.pada wanita menopause. Lama pemberian TSH adalah 6 bulan.Bahan penelitian terdiri dari 35 wanita menopause. Penelitian ini berlangsung dari Januari 2001 hingga Juni 2001. Setelah TSH 6 bulan terjadi penurunan yang bermakna terhadap FSH. Tidak dijumpai pengaruh TSH terhadap kadar bilinubin, namun dijumpai sedikit peningkatan enzim alkali fosfatase, serta peningkatan yang bermakna SGOT dan SGPT. menyebabkan penurunan kadar kolesterol total serta penurunan kadar trigliserida. Selain itu dijumpai sedikit peningkatan LDL, dan penurunan kadar HDL secara bermakna. TSH dengan progesteron sintetik noretisteron terjadi peningkatan sintesis kolagen kulit, yang ditandai dengan adanya peningkatan ketebalan kulit. yang bermakna. (Med J Indones 2002; 11: 97-103)
\end{abstract}

\begin{abstract}
This study was aimed to observe the effect of hormone replacement therapy (HRT) of estradiol $2 \mathrm{mg}+1 \mathrm{mg}$ acetate noretisterone administered continuously on FSH hormone, lipid profile, blood chemistry, and skin thickness in menopausal women. The duration of HRT administration was 6 months. The subjects of the study were 35 menopausal women. The study was conducted from January 2001 to June 2001. After HRT administration of 6 months, a significant decrease of FSH was observed. No effect of HRT was found in bilinubin level; however, there was a slight increase of alkali phosphatase enzyme, and a significant increase in SGOT and SGPT. $H R T$ caused a decrease of total cholesterol level and triglyceride level. In addition, a slight increase of LDL level and significant decrease of HDL level were observed. HRT administration with progesterone synthetic noretisterone showed an increase of skin collagen synthesis, which was indicated by the significant increase of skin thickness. (Med J Indones 2002; 11: 97-103)
\end{abstract}

Keywords: HRT, FSH, menopause, lipid profile, blood chemistry, skin thickness

Menopause is a physiological process which will be experienced by every woman. Estrogen deficiency results in the menstrual disorder leading to menstrual cessation. As a result of this estrogen deficiency, 50$60 \%$ of women will experience complaints which require medical help. One of the health problems attracting a great deal of attention of the countries in the world is osteoporosis. Nearly $40 \%$ of women approaching the age of 70 suffered from bone fractures associated with osteoporosis. ${ }^{1}$ The expenses incurred by a country in providing healthcare for bone fractures reach as high as billions of US dollars.

Department of Obstetrics and Gynecology, Faculty of Medicine University of Indonesial Dr. Cipto Mangunkusumo General Hospital, Jakarta, Indonesia
In view of the immense impacts brought about by osteoporosis, an early diagnosis of osteoporosis is extremely important. It may even be more important than the treatment and early prevention. HRT administration with estrogen or with combined estrogenprogesterone may prevent osteoporosis up to $50 \%{ }^{2}$

Up to the present, diagnosis of osteoporosis has normally been performed by observing the bones directly by means of radiology. The type of radiological examination commonly used is ratio isotop (single photon absorptiometer), Dual Photon Absorptiometry (DPA), Dual Energy X Ray Absorptiometry (DXA) and CT Scan. Unfortunately, these examinations are relatively expensive and carry the risk of radiation.

Currently, a simple and inexpensive examination tool of transdermal USG which carries no risk for patients has been developed. This tool is design to measure 
the skin thickness of woman. By measuring skin thickness (collagen), the presence of osteoporosis can be identified. Collagen in the bones consists of Gellatina, scleroprotein which serve to maintain the stability of bones. This type of collagen is also present in the skin and cardiovascular structure. Thus, this transdermal USG tool is actually designed to measure the collagen content in the skin. If the collagen content in the skin decreases, the collagen content in the bone will correspondingly decrease. The deficiency of collagen may result in wrinkled, inelastic skin, while such deficiency in the bone will contribute to the osteoporotic bones.

For the women who still have the uterus, estrogen should always be combined with progesterone in order to prevent the occurrence of endometrial hyperplasia. The type of estrogen and progesterone recommended is the natural one. Estradiol is the type of natural estrogen most frequently used. Its metabolism occurs in the liver, and its long-term use may occasionally interfere with liver functions. Nowadays, there are HRT specimens using synthetic progesterone, such as noretisterone. Progesterone of this type requires an activation in the liver to the extent that it may create a burden in the liver. In addition, noretisterone triggers the activity of lipoproteinlipase enzyme in the liver, which may result in the disruption of HDL and LDL metabolism. ${ }^{3,4}$

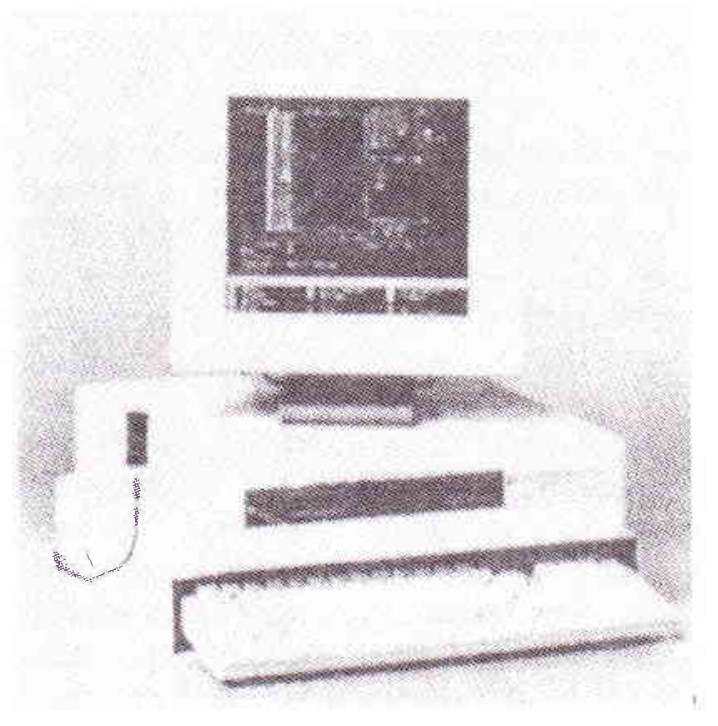

\section{MATERIAL AND METHODS}

The present study was designed as a non-comparative clinical trial. This stidy was also designed to evaluate the effect of continuo:s HRT administration before and after 6 months on FSH hormone, lipid profile, blood chemistry, and skin thickness in menopausal women. Every woman received HRT in the form of estradiol tablets $2 \mathrm{mg}$ an noretisterone acetate $1 \mathrm{mg}$ continuously. All patients still had the intact uterus and ovary. The subjects of the study were 35 patients of menopausal women admitted for treatment to Menopausal Clinic "Menox" in Jakarta from January 2001 to June 2001. History taking was undertaken in all patients covering identity, age, and education. There were also asked about history of previous disease and the presence of climacteric complaints. After meeting the criteria of inclusion and exclusion, the patients underwent the examination of FSH, alkali phosphatase, SGOT, SGPT, total cholesterol, triglyceride, LDL, HDL, ureum, and creatitine. The measurement of skin thickness was done using transdermal USG of Osteoson brand manufactured by Germany witı' high resolution (20 Mhz) (Fig. 1). Skin thickness was determined with either modus A or modus B. The skin area measured was the inside upper part of left arm.

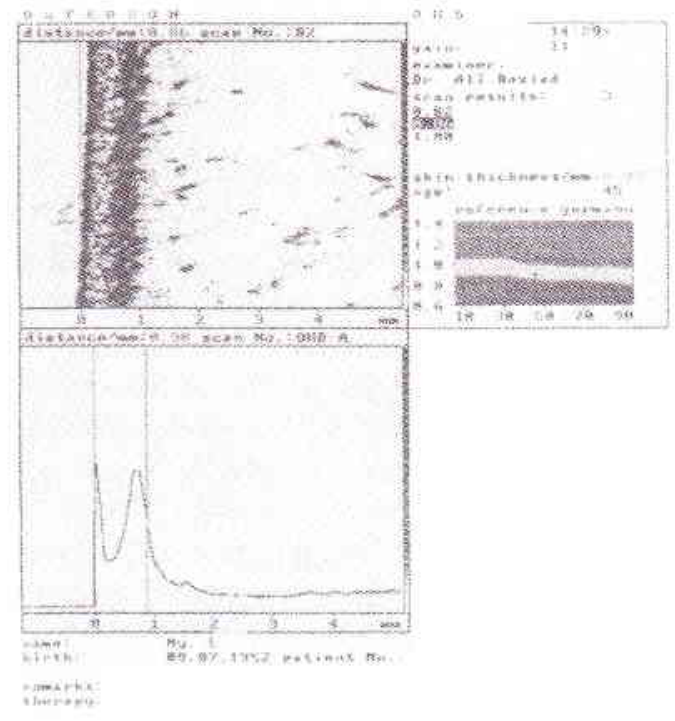

Figure 1. Ultrasound measurement of skin thickness 


\section{RESULTS}

Table 1. Mean value of several variables

\begin{tabular}{llc}
\hline No & \multicolumn{1}{c}{ Variable } & $\mathrm{x} \pm \mathrm{SEM}$ \\
\hline 1. & Age (year) & $52,4 \pm 0,76$ \\
2. & Duration of & $3,3 \pm 0,42$ \\
& menopause (year) & \\
\hline
\end{tabular}

Table 2. Education level

\begin{tabular}{lcc}
\hline Level & Frequency & \% \\
\hline Primary School & 2 & 5.7 \\
Junior High School & 9 & 25.7 \\
Senior High School & 8 & 22.9 \\
University graduate & 16 & 45.7 \\
\hline Total & 35 & 100 \\
\hline
\end{tabular}

Table 3. Effect of HRT on FSH hormone level

\begin{tabular}{|c|c|c|c|c|c|c|c|c|}
\hline \multirow{2}{*}{ Hormonal } & \multicolumn{3}{|c|}{0 month } & \multicolumn{3}{|c|}{6 month } & \multirow{2}{*}{$\mathrm{T}$ paired } & \multirow{2}{*}{$\mathrm{p}$} \\
\hline & $\mathrm{N}$ & Mean & SEM & $\mathrm{N}$ & Mean & SEM & & \\
\hline $\mathrm{FSH}(\mathrm{mIU} / \mathrm{ml})$ & 35 & 63.7 & 5.59 & 35 & 40.1 & 4.38 & 6.87 & $<0.01$ \\
\hline
\end{tabular}

Table 4. Effect of HRT on blood chemistry laboratory

\begin{tabular}{|c|c|c|c|c|c|c|c|c|}
\hline \multirow{2}{*}{ Blood chemistry } & \multicolumn{3}{|c|}{0 month } & \multicolumn{3}{|c|}{6 month } & \multirow{2}{*}{$\mathrm{T}$ paired } & \multirow{2}{*}{$\mathrm{p}$} \\
\hline & $\mathrm{N}$ & Mean & SEM & $\mathrm{N}$ & Mean & SEM & & \\
\hline Bilirubin (mg/dl) & 35 & 0.6 & 0.04 & 35 & 0.6 & 0.06 & -0.33 & $>0.05$ \\
\hline Alkali phosphatase $(\mathrm{u} / \mathrm{l})$ & 35 & 180.2 & 8.69 & 35 & 186.2 & 10.09 & -0.56 & $>0.05$ \\
\hline SGOT $(\mathrm{u} / \mathrm{l})$ & 35 & 19.5 & 0.82 & 35 & 27.5 & 1.17 & -6.79 & $<0.01$ \\
\hline SGPT (u/l) & 35 & 18.7 & 1.31 & 35 & 24.1 & 1.30 & -3.24 & $<0.01$ \\
\hline Ureum mg/dl) & 35 & 26.5 & 1.16 & 35 & 22.9 & 1.04 & 2.78 & $<0.01$ \\
\hline Creatinine (mg/dl) & 35 & 0.9 & 0.02 & 35 & 0.9 & 0.03 & 0.36 & $>0.05$ \\
\hline
\end{tabular}

Table 5. Effect of HRT on lipid profile

\begin{tabular}{|c|c|c|c|c|c|c|c|c|}
\hline \multirow{2}{*}{ Blood chemistry } & \multicolumn{3}{|c|}{0 month } & \multicolumn{3}{|c|}{6 month } & \multirow{2}{*}{$\mathrm{T}$ paired } & \multirow{2}{*}{$\mathrm{p}$} \\
\hline & $\mathrm{N}$ & Mean & SEM & $\mathrm{N}$ & Mean & SEM & & \\
\hline Total cholesterol (mg/dl) & 35 & 224.5 & 4.56 & 35 & 218.1 & 5.02 & 1.74 & $>0.05$ \\
\hline Triglyceride (mg/dl) & 35 & 132.8 & 14.73 & 35 & 127.2 & 13.6 & 0.543 & $>0.05$ \\
\hline $\mathrm{LDL}(\mathrm{mg} / \mathrm{dl})$ & 35 & 144.74 & 5.73 & 35 & 146.5 & 7.25 & -0.32 & $>0.05$ \\
\hline $\mathrm{HDL}(\mathrm{mg} / \mathrm{dl})$ & 35 & 58.7 & 2.21 & 35 & 54.3 & 2.49 & 2.09 & $<0.05$ \\
\hline
\end{tabular}

Table 6. Effect of HRT on skin thickness

\begin{tabular}{|l|ccc|ccc|c|c|}
\hline \multirow{2}{*}{ Note } & \multicolumn{4}{|c|}{ 0 month } & \multicolumn{3}{c|}{ T month paired } & \multirow{2}{*}{ p } \\
\cline { 2 - 8 } & $\mathrm{N}$ & Mean & SEM & $\mathrm{N}$ & Mean & SEM & & \\
\hline Skin thickness $(\mathrm{mm})$ & 35 & 0.93 & 0.069 & 35 & 0.94 & 0.072 & -5.774 & $<0.01$ \\
\hline
\end{tabular}




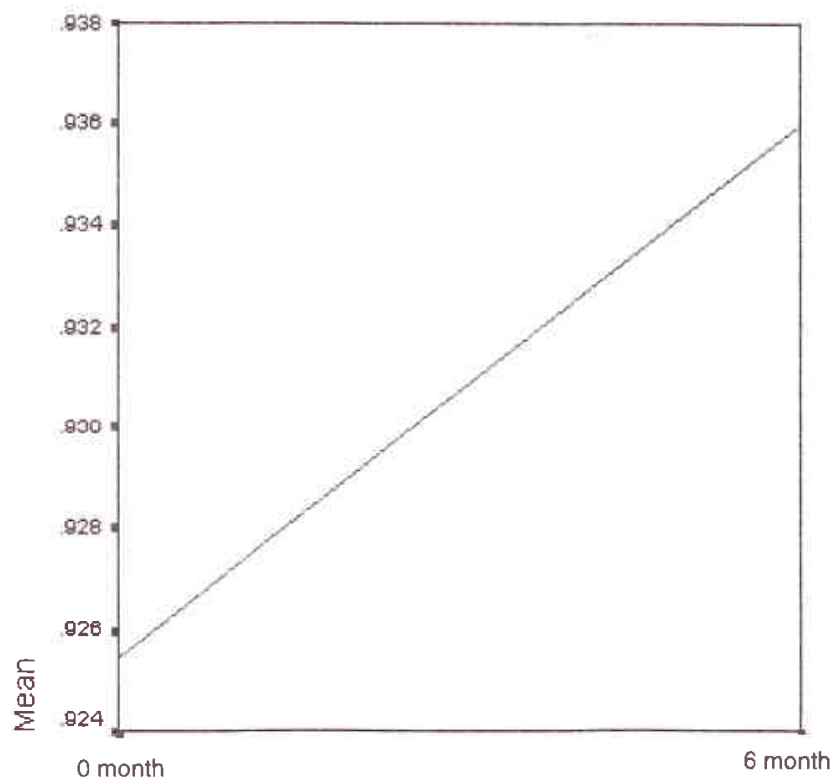

Figure 2. The effect of HRT on skin thickness

\section{DISCUSSION}

In 1984, the average age of menopause in Indonesia was 48 years. ${ }^{5}$ In this study, the average age found was 52.4 years. This finding was not much different from the average age of menopause in the developed countries, i.e., approximately between 50 and 51 years. ${ }^{6,7}$ The increased age of menopause in Indonesia may be attributed to the improved nutrition, and the evident improvement of living standard of the majority of Indonesian women.

In this study, the patients had generally experienced menopause 3.3 years ago with most education level of university graduate $(45.7 \%)$. In terms of duration of menopause, all patients were still at the stage of early menopause. Since a part of the patients had education level of junior high school and higher, it was hoped that each patient could take the medication regularly and appropriately. The irregularity, in taking the medication frequently resulted in bleeding, and this may caused patients to experience a disorder and to discontinue therapy. Table 3 shows that after termination of therapy a significant decrease of FSH level was still found $(\mathrm{p}<0.01)$. This shows sufficient effectiveness of the medication in the body in eliminating the effects due to estrogen deficiency.
In the laboratory examination of blood chemistry, a significant change of bilirubin level was found. HRT in fact has some effect on bilirubin. ${ }^{8}$ In postmenopausal women, the level of alkali phosphatase was normal or slightly increased due to the increase of bone resorption. ${ }^{9,10}$ The long-term administration of HRT (> 1 year) may reduce the level of alkali phosphatase. ${ }^{11,12}$ In this study, a slight increase of alkali phosphatase level was found after the administration of HRT for 6 months, which is statistically not significant ( $p>0.05$ ). This shows an increase of bone resorption in all patients studied who may have developed osteoporosis in the future if they had not been treated.

In the present study, the administration of HRT shows a significant increase of SGOT and SGPT levels; however, this increase was still within the normal values (normal value of SGOT was 11-36 $\mu / 1$, and SGPT was $10-65 \mu / \mathrm{I})$. In the postmenopausal women, an increase of both SGOT and SGPT levels were found, and the administration of estrogen may cause an increase of those enzymes. ${ }^{12,13,14}$ Therefore, caution should be exercised in using HRT in women with liver disorder.

Generally in the postmenopausal women there is a decrease of creatinine secretion through urine. ${ }^{15}$ With 
HRT administration, the secretion of urine was found to return to normal condition. ${ }^{16,17}$ In the present study, no change in the level of serum creatinine was found after the administration of HRT for 6 months. Generally the ureum level in postmenopausal women slightly increases, and with HRT administration its level may return to normal or slightly decrease. ${ }^{18}$ From Table 4 it is evident that after HRT administration the ureum level decreased significantly; however, this decrease was still within the normal limits (normal limit: $10-50 \mathrm{mg} / \mathrm{dl}$ ).

From epidemiological study it was proved that the decrease of total cholesterol up to 2-3\% may reduce the risk of coronary heart disease by $1 \%$. ${ }^{18}$ The administration of estrogen with or without a combination with progesterone may reduce the level of total cholesterol by $10-20 \%{ }^{19,20}$ In this study, a decrease in the level of total cholesterol from 224.5 $\mathrm{mg} / \mathrm{dl}$ to $218.1 \mathrm{mg} / \mathrm{dl}$ and a decrease of triglyceride level from $132.8 \mathrm{mg} / \mathrm{dl}$ to $127.2 \mathrm{mg} / \mathrm{dl}$ were found after the administration of HRT for 6 months, although these decreases were not statistically significant (normal value of total cholesterol: 150-225 $\mathrm{mg} / \mathrm{dl}$, triglyceride: $40-145 \mathrm{mg} / \mathrm{dl}$ ).

From various studies it was evident that high HDL level has protective properties for the heart, ${ }^{21,22}$ while high LDL level increases the risk of coronary heart disease. ${ }^{21}$ In this study, a slight increase of LDL level was found after the administration of HRT for 6 months, i.e., from $144.75 \mathrm{mg} / \mathrm{dl}$ to $146.5 \mathrm{mg} / \mathrm{dl}$ (p > $0.05)$. However, this increase was still within normal values $(60-160 \mathrm{mg} / \mathrm{dl})$. After 6 months of therapy, a significant decrease of LDL level was found. This decrease was not hazardous since its values were still within the normal limits ( normal HDL: $45-80$ $\mathrm{mg} / \mathrm{dl}$ ). The decrease of HDL level was closely associated with the type of progesterone used. Synthetic progesterone such as noretisterone has been proved to reduce the level of HDL serum and may increase the level of LDL serum. ${ }^{19,23}$ Natural progesterone such as medroxy progesteronacetate (MPA) proved to slightly affect lipid metabolism. ${ }^{24}$ The administration of noretisterone $10 \mathrm{mg}$ in women before menopause who underwent the removal of both ovaries caused an increase of LDL level by $13 \%$, decrease of HDL by $35 \%$, while the administration of natural progesterone such as MPA proved to have no effect on lipid metabolism. ${ }^{24,25}$ In this study, a significant decrease of HDL level was found, but this was followed by a significant increase of total cholesterol level, in addition to the decreased level of triglyceride. Metabolic changes felt were not disturbing, this is because the European Atheroschlerosis Society stated that lipid disorder could only occur if total cholesterol level was found above $300 \mathrm{mg} / \mathrm{dl}$, triglyceride level was above $200 \mathrm{mg} / \mathrm{dl}$, and HDL level was below $35 \mathrm{mg} / \mathrm{dl}^{26}$

Table 6 shows that the average skin thickness before therapy was $0.93 \mathrm{~mm}$, which means that all the collagen levels of all patients have decreased. Normal values of skin thickness were above $1.0 \mathrm{~mm} .{ }^{1,27} \mathrm{In}$ the condition of prolonged estrogen deficiency a decrease of collagen synthesis may occur in the skin and bones. ${ }^{22}$ In 1987, Brincat ${ }^{27}$ found a decrease in the collagen level of the skin and bone with the increase of age. Brincart ${ }^{28}$ also showed that up to the age of 50 the skin thickness of women is relatively stable; however, due to estrogen deficiency the skin thickness gradually diminishes. ${ }^{28}$ On the other hand, Shuster ${ }^{29}$ suggested that with the increase of age every year women will lose skin collagen by $1 \%$. From the results showed in Table 6 , it may be concluded that all those women have experienced osteoporosis since their skin thickness was on the average below $1.0 \mathrm{~mm}$.

Unfortunately, transdermal USG does show which bones have undergone osteoporotic process. Transdermal USG only provides a description on the amount of skin collagen still possessed by a woman. After 6 months of therapy, a significant increase of skin thickness was found $(\mathrm{p}<0.01)$. The increase of skin thickness largely depends on the type of progesterone used. The study conducted by Baziad et $\mathrm{al}^{30}$ in 1994 did not show any significant increase of skin thickness in the postmenopausal women receiving conjugated estrogen tablet $0.625 \mathrm{mg} / \mathrm{day}+$ Dydrosgesterone tablet $10 \mathrm{mg} / \mathrm{dl}$ for a period of one year. This may be attributed to the fact that the type of progesterone used was of natural type. By contrast, in the present study the type of progesterone used was noretisterone, which is a synthetic progesterone. Several investigators have proved that an addition of 5 $\mathrm{mg}$ noretisterone cyclically in the postmenopausal women resulted in the increase of skin collagen by $50 \%{ }^{27,31}$ However, there is still controversy as to whether the increase of such collagen level is really due to testosterone-derived hormone such as noretisterone. In fact, the level of blood androgen in the menopausal women is sufficiently high, yet it is the question to be answered why the collagen level in those women remains low and they are vulnerable to osteoporosis. Only after HRT administration with estrogen, can the increase of collagen synthesis in the 
skin and bones be observed. It can be concluded that the most important factor in the increase of collagen level is the role of estrogen. On the other hand, noretisterone only serves to facilitate the work of estrogen in the skin and bones. The increase of progesterone in the HRT agent is in fact aimed to prevent women from being attacked with endometrial cancer.

\section{CONCLUSIONS}

The average age of menopause in this study was $\mathbf{5 2 . 5}$ years and the average duration of menopause was 3.3 years. As many as $45.7 \%$ of patients had education level of university graduate. No changes in bilirubin level after the administration of HRT for 6 months. There was a slight increase of akali phosphatase after the therapy. A significant increase of SGOT and SGPT levels was found; however, this increase was still within the normal limits. In addition, there was a decrease in total cholesterol and triglyceride levels after 6 months of therapy. The administration of testosterone-derived synthetic progesterone, such as noretisterone, resulted in the slight increase of LDL level, and significant decrease of HDL level. This decrease was not hazardous as it was still within the normal limits for HDL. HRT with natural estrogen + synthetic noretisterone progesterone resulted in the significant increase of skin thickness.

\section{REFERENCES}

1. Kuhl H, Taubert HD. Postmenopausale Osteoporosis. In: Das Klimakterium. Georg Thieme Verlag. Stuttgart-New York, 1987: 291-322

2. Conference Report Consensus Development Conference: prophylaxis and treatment of osteoporosis. Br med J. 1987; 295: 914-6

3. Tikkanen MJ, Nikkila EA, Kuusi T, Sipinen S. High density lipoprotein-2 and hepatic lipase: reciprocal changes produced by estrogen and norgestrel. J clin Endocr 1982; $54: 1113-17$

4. Tikkanen MJ, Nikkila T, Kuusi T,Sipinen S. Different effects of two progestins on plasma high density lipoprotein (HDL2) and postheparin plasma hepatic lipase activity. Atherosclerosis 1981; 40: 365-69

5. Agustina T, Keep PAV. The climacteric in Bandung, West Java Provinces, Indonesia. Maturitas 1984; 6: 333-72

6. Krailo MD, Pike MC. Estimation of the distribution of age at natural menopause from prevalence data. Am J Epidemiol 1983; 117:356

7. Birkhauser M, Braendle W, Breckwoldt M, Keller PJ, Kuhl H, Runnebaum B. Empfehlungen des "Zurcher Gesprachskreises" zu Substitution mit Estrogenen und
Gestagenen im Klimakterium und in der Postmenopause. Frauenarzt 1999; 40: 153-55

8. Kuhl H, Jungh-Hoffmann C, Storch A, Fitzner M, Ruhl E. New aspects on the mechanism of action of contraceptive steroids - recent pharmacokinetic studies of low dose formulations. Adv Contracep 1991; 3: 149-63

9. Christiansen $\mathrm{C}$, Christensen MS, McNair P, Hagen C, Stocklund KE, Transbol I. Prevention of early postmenopausal bone loss; controlled 2-year study in 315 normal females. Europ J clin Invest 1980; 10: 273-79

10. Christiansen C, Christensen MS, Larsen NE, Transbol I. Pathophysiological relationships of estrogen effect on bone metabolism. Dose-response relationships in early postmenopausal women. J clin Endocr 1982; $55: 1124-30$

11. Daniell HW. Osteoporosis of the slender smoker. Arch intern Med 1976; 136:298-304

12. Moore B, Paterson MEL, Sturdee DW, Whitehead TP. The effect of menopausal status and sequential mestranol and noretisterone on serum biochemical profiles . Brit J Obstet Gynaec 1981; 88 : 853-58

13. McPherson K, Healy MJR, Flynn FV, Piper KAJ, GarciaWeeb P. The effect of age, sex and other factors on blood chemistry in health. Clin chim Acta 1978; $84: 373$ - 97

14. Hodgkinson A. Biochemical changes at the menopause: possible role of the central nervous system. Maturitas $1984 ; 6: 259-67$

15. Gambert SR, Tsitouras PD, Duthie EH. Interpretation of laboratory results in the elderly. A clinician's guide to endocrine tests. Postgrad med J 1982; 72 : 251-56

16. Lobo RA, Brenner P, Mishell DR. Metabolic parameters and steroid levels in postmenopausal women receiving lower doses of natural estrogen replacement. Obstet Gynec $1983 ; 62: 94-8$

17. Jones MM, Pearlman B, Marshall DH, Crilly RG, Nordin BEC. Dose-dependent response of FSH, flushes and urinary calcium to oestrogen. Maturitas 1982;4:285-90

18. Kuhl H. Klimakterium, Postmenopause und Hormon substitution. Unimed Verlag, Bremen 1999; 95 - 101

19. Kuhl H. Metabolische Effekte der Ostrogene und Gestagene. Gynakologe $1997 ; 30: 357-69$

20. Kuhl $\mathrm{H}$. Cardiovascular disease and estrogen replacement therapy - epidemiological data. In : Lippert TH, Muck AO (eds). Sex Steroids and the Cardiovascular System. Pathernon London. 1998: 97 - 109

21. Levy RI. Cholesterol, lipoproteins, apoproteins, and heart disease: present status and future prospects. Clin Chem $1981 ; 27: 653-61$

22. Fisch FH, Huber JC. Die Hormonsubstitution in Wandel der Zeit. Krause \& Pachernegg GmbH, Gabliiz, 2000 : $119-27$

23. Tikkanan MJ, Kuusi T, Nikkila EA, Sipinen S. Postmenopausal hormone replacement therapy: effects of progestogens on serum lipids and lipoproteins. A review. Maturitas 1986; 8:7-17

24. Pickar JH, Wild RA, Walsh B, Hirvonen E, Lobo RA. Effects of different hormone replacement regimens on postmenopausal women with abnormal lipid levels. Climacteric 1998; $1: 26-31$

25. Silfverstolpe G, Gustafson A, Samsioe G, Svanborg A Lipid metabolic studies in oophorectomised women: effect on serum lipids and lipoproteins of three synthetic progestogens. Maturitas 1980;2:103-11 
26. Study Group, European Atherosclerosis Society. Strategies for the prevention of coronary heart disease: A policy statement of the European Atherosclerosis Society. Eur Heart J 1987; $8: 77$

27. Brincart M, Wong TYA. Response of skin thickness and metacarpal to estradiol therapy in postmenopausal women. Obstet Gynec 1987; $70: 538$

28. Brincart M, Moniz CJ, Stid WW, Darby A, Mayor G, Embury G, Verti E. Long-term effects of the menopause and sex hormones on skin thickness. Br J Obstet Gynaecol $1985 ; 92: 256-9$
29. Shuster S, Blach MM, Verti E. The informed of age and on skin thickness, skin collagen and density. Brit J Derm $1975 ; 93: 639-43$

30. Baziad A, Salim A, Hestiantoro A, Kuhl H. Pengukuran ketebalan kulit untuk deteksi dini osteoporosis dengan USG transdermal pada wanita menopause yang mendapat terapi substitusi. Maj Obstet Ginekol Indones 1997; 21 : $109-13$

31. Punnonen R, Vilska S, Rauramo L. Skinfold thickness and long-term post-menopausal hormone therapy. Maturitas $1984 ; 5: 259-62$ 